\title{
Promoting Simulation-Based Learning through Low-Cost Simulators: Development, Skills targeted and Implementation
}

Inaaya Fatima Khan ${ }^{1}$, Youness Zidoun $\mathrm{PhD}^{2 *}$, Sharon Mascarenhas $\mathrm{MSc}^{2}$, Nabil Zary MD, $\mathrm{PhD}^{2}$

1. GEMS Founders, Dubai, United Arab Emirates

2. Institute for Excellence in Health Professions Education (ieHPE), Mohammed Bin Rashid University of Medicine and Health Sciences, Dubai, United Arab Emirates

*Corresponding author:

Youness Zidoun, $\mathrm{PhD}$

Institute for Excellence in Health Professions Education (ieHPE)

Mohammed Bin Rashid University of Medicine and Health Sciences (MBRU)

Dubai, United Arab Emirates

Email. Youness.Zidoun@mbru.ac.ae 


\begin{abstract}
Background: Simulations have historically aided training programs by providing a realistic and holistic replication of professional scenarios and procedures. Simulations have developed over the past 40 years to include varying fidelities and modalities of simulation. Learning in a simulationcentered environment has benefits, ranging from improved patient care to specific skills acquisition while catering to students' numerous and varied learning approaches. Simulation is a multifaceted field that benefits all parties, the teachers, the learners, and the patients. The application of simulation to medical education and its amalgamation with other modes and substitutes allows for a more integrated learning and testing curriculum that advances the current trajectory of medical education. Such developments, however, are limited to resource rich areas, leaving behind low-middle income countries to use traditional, less evolved methodologies and practices. This review aimed to explore different aspects of simulation and focus specifically on low-cost task trainers and their accessibility.
\end{abstract}

Method: The purpose of the study was to assess the accessibility of low-cost task trainers in terms of cost-effectiveness, distribution, validation, and frequency within specific specialties. To do so, 84 PubMed publications have been screened, and 39 filtered research studies have collected the necessary data. After analyzing the papers, we classified the following information - process, specialization, validation $(\mathrm{y} / \mathrm{n})$, costs, development location, and year of publication.

Results: After carefully analyzing the accumulated data from the selected 39 publications, we found that most studies (i.e., 6 out of 39) were published in 2020. Emergency Medicine was the most common specialty for which low-cost trainers were developed ( 9 out of 39 procedural simulators); Otolaryngology followed this with 8 out of 39 trainers and general surgery with 7/39 of the task-trainers. The price ranges fluctuated and fell within the price bracket of USD 0 to USD 400 collectively. Our review also uncovered the concentration of development of such innovations solely in high income countries (HICs).

Conclusion: Simulation is an invaluable tool applicable to a diverse range of phases of medical education. Future conjunction of simulation with low-cost substitutes along with increased encouragement and enthusiasm towards developing cost effective simulation-based learning environments (SBLEs) with the reserves and requirements of these areas in mind may prove to be a reliable option for low and middle resource settings

Keywords: Medical Education, Simulation, Low-Cost, Task trainers, procedural trainers 


\section{Introduction}

The word simulation is derived from the Latin root 'simulare' or 'similis', meaning to imitate or resemble. Thus, simulations act as substitutes for real life experiences by producing realistic reactions to life-like stimuli. In essence, simulations are enactments or replicas of existing or theoretical processes used as training, testing, and validating the processes.

Modern clinical simulations have more recent origins, gaining traction in the $20^{\text {th }}$ century with the creation of the 'Resusci-Anne'- a task trainer designed to practice cardiopulmonary resuscitation (CPR), simulations then evolved not only in function but also in efficacy as inferred by the creation of the Harvey mannequin, the functions of which extend to the replication of over 25 cardiopulmonary functions. As of the $21^{\text {st }}$ century, efforts have been made to make medical simulations more affordable, accessible, and comprehensive by contrasting simulation techniques with pre-existing methodologies and providing possible alternatives.

\section{Why is Simulation important?}

Medical Simulations have revolutionized current medical education pedagogy by ensuring students and professionals follow a step-by-step process to achieve a complete theoretical and practical understanding of the procedure. Simulation based learning allows qualified individuals to reach hierarchic stages of competence by confidently combining theoretical knowledge with diagnostic reasoning in "realistic, immersive educational environments"[1].

As illustrated in figure 1, students can start by relaying their existing knowledge and add on by watching more experienced personnel in action. They can then move on to the next stage by engaging in case specific procedures, then they may demonstrate their knowledge of the procedure on a simulator, and finally, after multiple simulated practices, they may carry out the procedure on a live patient. This is a classic example of Miller's Pyramid of Clinical Competence [2] shown in figure 1- a method developed to modify the 'monkey see, monkey do' learning style and ensure the addition of stages that ensure a complete and meticulous understanding of the procedure itself. Students, Residents, and healthcare professionals have increased access to procedural skills training and performance reports with simulated procedures. 


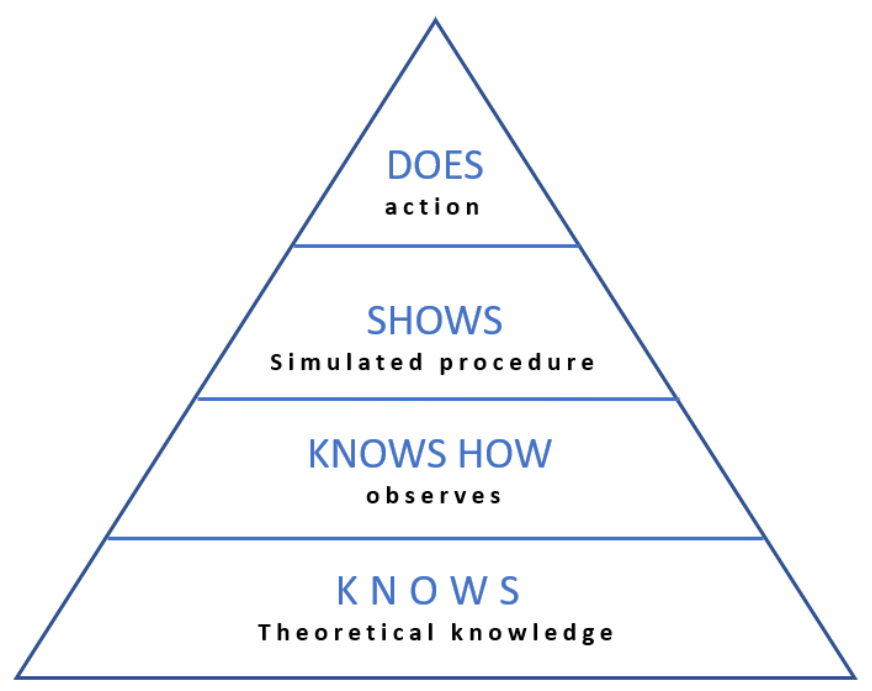

Figure 1. Miller's Pyramid of Clinical Competence in the context of simulation-based learning Additionally, using a monomodal approach of teaching that utilizes a single sensory experience, i.e., visual, auditory, kinesthetic, or haptic limits the scope of comprehension and may lead to negative transfer effects when applying knowledge to real life. Data collected from a study concerning learning styles conducted amongst medical students $(n=146)$ showed a preponderant preference for multimodal techniques (72.6\%) over unimodal ones [3]. Fewer procedural errors reduce procedure time and decrease costs significantly by avoiding additional expenses on procedures required to rectify errors, thereby acting as a return investment. Furthermore, simulation-based learning (SBL) dispenses a method of practicing low-occurrent, more distinctive procedures in a safe and risk-free setting. The U.S Institute of Medicine surmises "Thus, mistakes can best be prevented by designing the health system at all levels to make it safer--to make it harder for people to do something wrong and easier for them to do it right. [4]

According to the report published by the U.S. Institute of Medicine in 1999 - 'To Err is Human: Building a Safer Health System', 44,000 to 98,000 people die of preventable medical errors annually[4]. In addition, more recent articles suggest that more than 400,000 lives are lost per year as a result of iatrogenesis - the third leading cause of death in the U.S.A [5].

These figures raise the issue of patient safety and comfort. Simulations allow professionals to get abundant practice on task trainers before performing the procedure on the patient. Studies show that computer simulation training enhances patient comfort during endoscopies. Patients whose endoscopies were performed by students who underwent simulation-based training reported 
significantly less discomfort than those who were treated by students who underwent patient based training [6].

Kevin Kunkler summarizes it well - 'Simulators are useful tools in determining a physician's understanding and use of best practices, management of patient complications, appropriate use of instruments and tools \& overall competence in performing procedures" [7].

The simulators used in medical schools and teaching hospitals vary depending on cost, fidelity, and modality.

Table 1. differentiates between fidelity and modality in the context of simulators.

\begin{tabular}{|c|l|}
\hline Modality & $\begin{array}{l}\text { The type of simulation being employed to practice a particular procedure in } \\
\text { accordance with simulated or synthetic learning methods. }\end{array}$ \\
\hline \multirow{3}{*}{ Fidelity } & $\begin{array}{l}\text { The degree to which a simulation accurately represents an actual procedure } \\
\text { and produces interactions on par with its tangible life equivalent. Depending } \\
\text { on the extent of realism, fidelity can be classified as low or high. Fidelity is } \\
\text { multifaceted and can also be conceptual, environmental, functional, physical, } \\
\text { and/or psychological. }\end{array}$ \\
\hline
\end{tabular}

Table 2. shows the typology of modalities in clinical simulation. [8]

\begin{tabular}{|c|l|}
\hline Modality & \multicolumn{1}{c|}{ Description } \\
\hline Partial Task Trainers & $\begin{array}{l}\text { A device used to simulate a specific procedural technique. Economical, useful } \\
\text { for regular practice. }\end{array}$ \\
\hline $\begin{array}{c}\text { Realistic Patient } \\
\text { mannikin }\end{array}$ & $\begin{array}{l}\text { High fidelity externally controlled mechanical models of patients with } \\
\text { human-like physiology. Can simulate complex conditions while providing } \\
\text { high degree of realism. However, inaccessible, expensive, time consuming, } \\
\text { and resource intensive. }\end{array}$ \\
\hline $\begin{array}{c}\text { Immersive Reality } \\
\text { Patients }\end{array}$ & $\begin{array}{l}\text { Use of technology to create a three-dimensional virtual interface wherein the } \\
\text { student can practice in an interactive \& multi-dimensional environment. }\end{array}$ \\
\hline Simulated/Standardized & $\begin{array}{l}\text { People who have been carefully trained to simulate a real patient. It can be } \\
\text { used to practice communication and debriefing skills. However, simulations } \\
\text { are limited. }\end{array}$ \\
\hline Hybrid Simulation & $\begin{array}{l}\text { Combining modalities to increase realism via a multimodal simulation. E.g., } \\
\text { Application of a partial task trainer on a simulated patient. }\end{array}$ \\
\hline
\end{tabular}




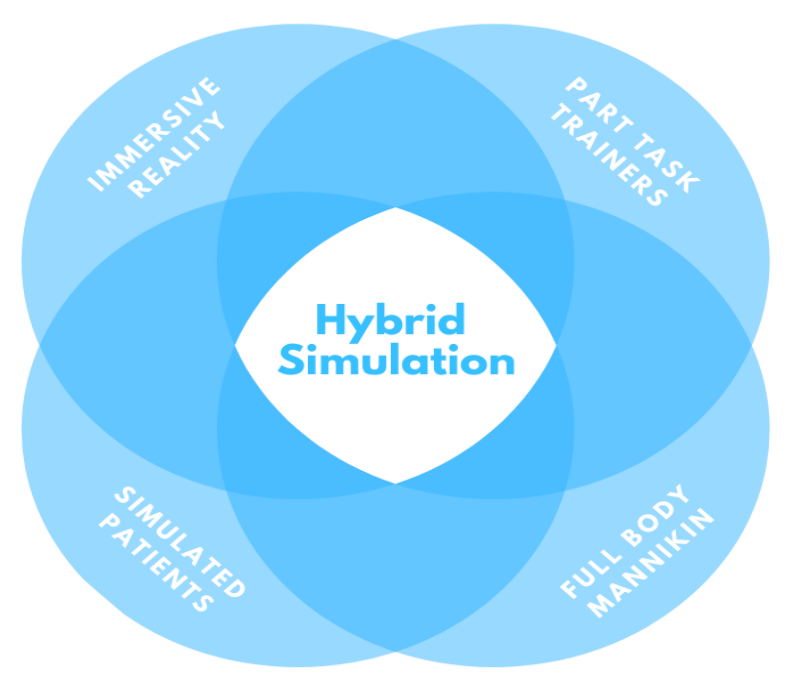

Figure 2. Visual representation of simulation modalities

Table 3 describes the different fidelities in clinical simulation. [9]

\begin{tabular}{|c|l|}
\hline $\begin{array}{c}\text { Type of } \\
\text { Fidelity }\end{array}$ & \\
\hline High & Refers to highly realistic simulators. \\
\hline Low & Manual simulators with no computer-based or external input. \\
\hline Conceptual & $\begin{array}{l}\text { Refers to the accuracy of data, ensures supplementary information is consistent with } \\
\text { diagnosis/case study. }\end{array}$ \\
\hline Environmental & The degree to which simulated environment resembles the real environment. \\
\hline Functional & The extent to which the simulator complements the individual's actions. \\
\hline Physical & The extent to which simulator embodies the real task. \\
\hline Psychological & Degree to which individual internalizes realism provided by the simulator. \\
\hline
\end{tabular}

Often, more costly, high-fidelity simulators are equated with having higher efficacy. However, contradictory meta-analysis of 24 studies involving both low and high-fidelity learning showed that both simulations resulted in consistent improvement as compared to a control group, but no significant advantage was found of high-fidelity simulation (HFS) over low-fidelity simulation (LFS), any and all differences ranged from 1-2\%.[10] 
Furthermore, research suggests that while there is no significant advantage of HFS over LFS, students practicing with HFS tend to be more overconfident [11].

The technology employed in some modalities of simulation is not widespread. Students and professionals in low to middle income countries (LMICs) cannot experience the same simulations as those in high income countries (HICs). The simulations developed in HICs are biased to cultural, economic, and logistical standards that favor their actuality. The same developments cannot be generalized to LMICs due to the vast distinction between the two variables. Healthcare workers in LMICs are subjected to a repetitive cycle of needing to train students but not having the time, and in scenarios when time is not a constraint, resources are. This is something that is referred to as an "education paradox" [12].

To bridge this gap between resources available to individuals in HICs and those in LMICs, lowcost simulators created from easily obtained materials are developed and validated. In addition, numerous self-assembled \& cost-effective alternatives such as hybrid simulation, moulage, 3D printing using available, biodegradable filaments such as PLA can be used to substitute for the lack of prefabricated simulators in these areas.

Therefore, to effectively address the facets mentioned above of simulation and its more attainable forms whilst trying to gauge the potential of such devices, we have scoped a diverse assortment of publications and compiled their findings in this review of the literature.

This study aims to review:

- How are low-cost simulators developed and their cost effectiveness?

- What are the procedural skills practiced using low-cost simulators?

- Where are low-cost simulators developed and implemented? 


\section{Method}

To acquire the required data and filter it into the relevant categories. Our search strategy involved title and abstract based analysis of publications, including the keywords: "low cost - task trainer". Upon reviewing 84 publications acquired from PubMed and filtering the relevant articles dated between 2005 and 2021, we categorized the specialty the device is specific to, whether the model has been validated or not, the price range, how recently and where the model was developed. The documentation of the selection process was conducted following PRISMA

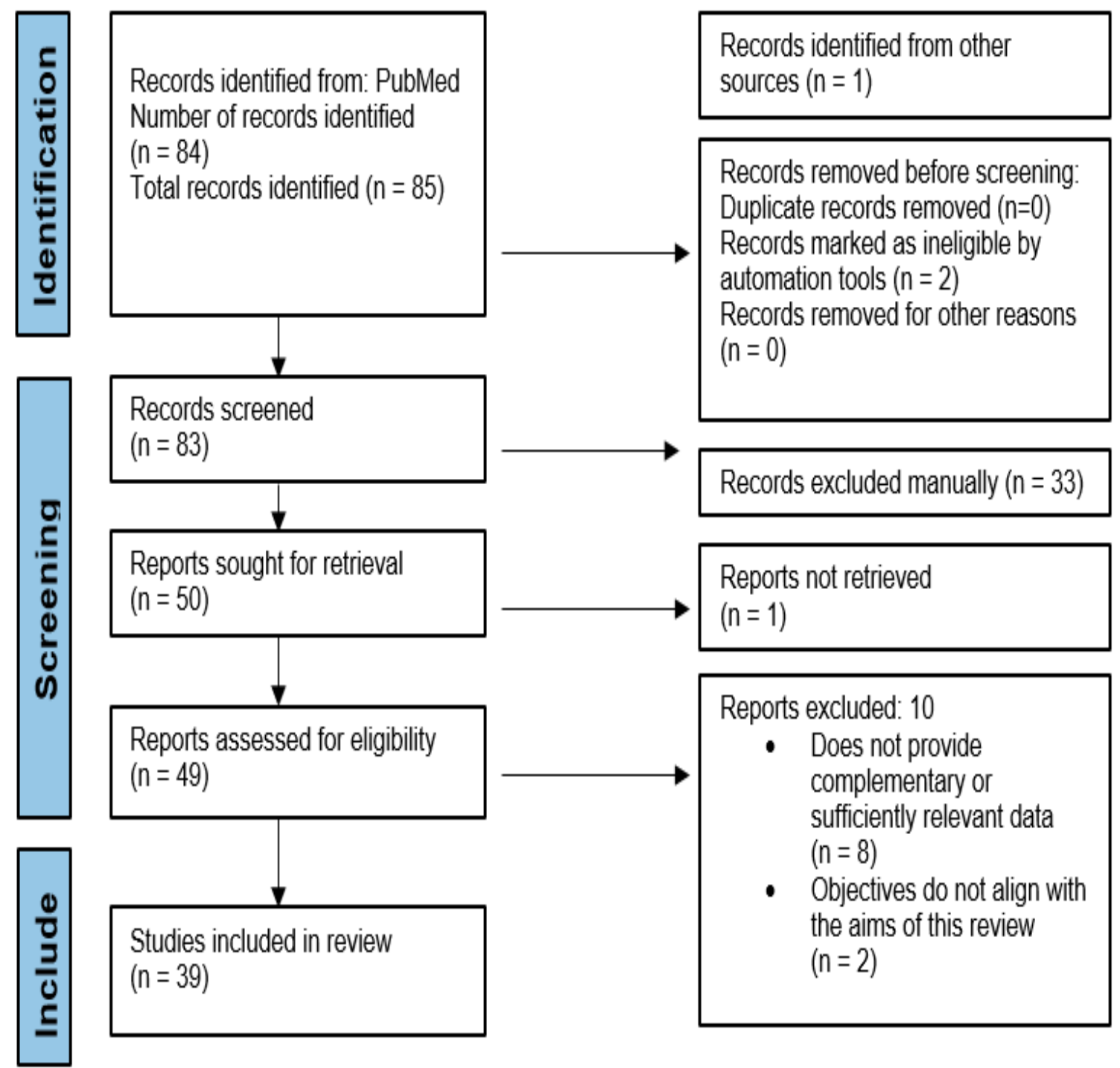

Figure 3. Systematic review of relevant publications following PRISMA 


\section{Results}

The following linear diagram depicts the included studies' incidence spanning 16 years between 2005 and 2021.

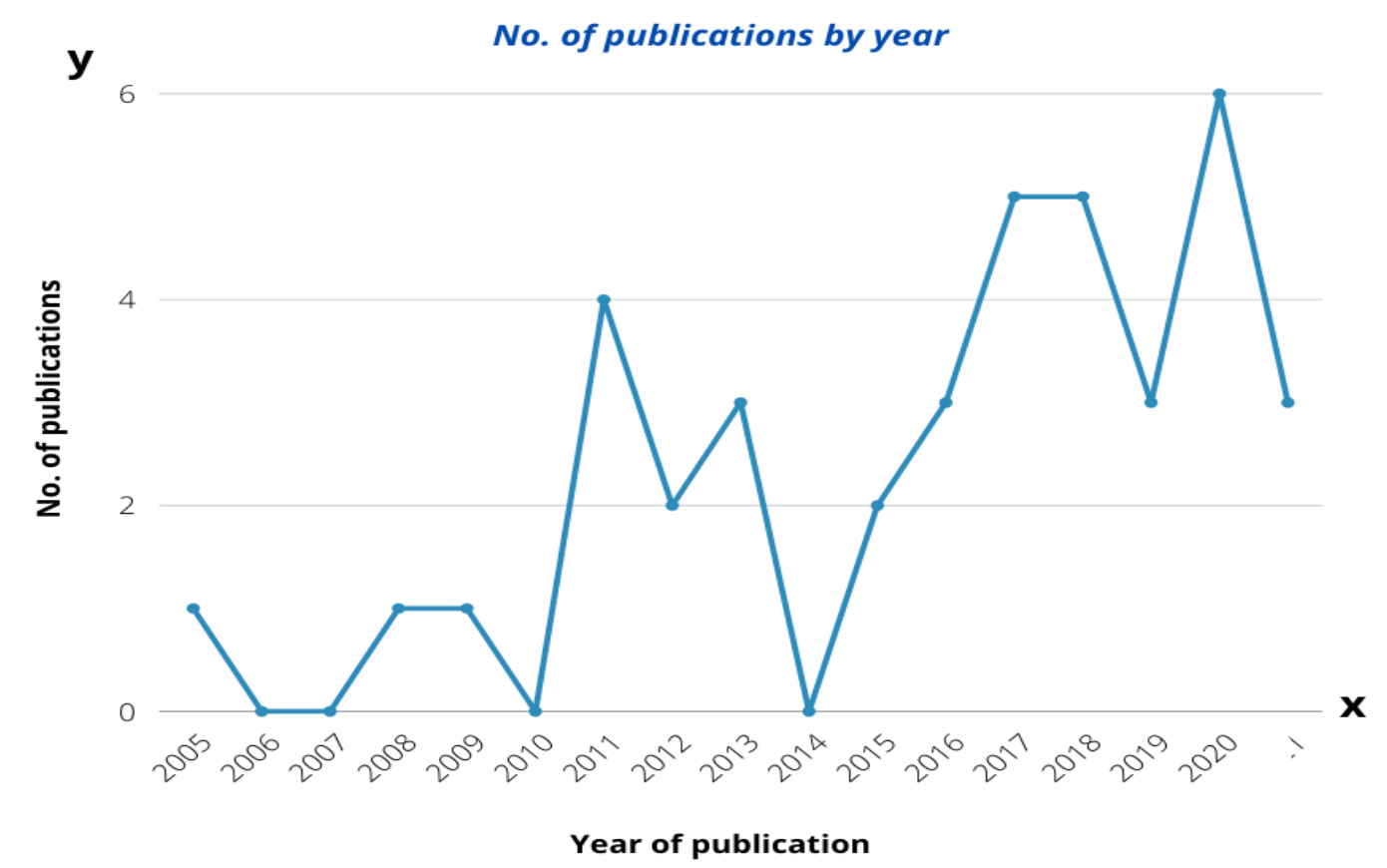

Figure 4. The frequency of publication related to low-cost task trainers

The linear graph gives a broad understanding of the spread of the selected publications over the years. The trend shows a sharp increase in publications on 'low-cost task trainers' from 2011 onwards, peaking in 2020 with 6 out of 39 studies.

The table below summarizes our findings extensively and categorizes them into the criteria named earlier. 
Table 4 gives an extensive overview of the procedures, specialties, costs, validity, place, and year in which the subjects of the included records were developed.

\begin{tabular}{|c|c|c|c|c|c|c|c|}
\hline $\begin{array}{l}\text { S. } \\
\text { No. }\end{array}$ & Publication & Procedure & Specialty & $\begin{array}{c}\text { Validated } \\
\mathbf{y} / \mathbf{n}\end{array}$ & $\operatorname{Cost}^{1 *}$ & Place & Year \\
\hline 1 & $\begin{array}{l}\text { Construct validity of a low-cost } \\
\text { medium-fidelity endoscopic } \\
\text { sinus surgery simulation model } \\
{[13]}\end{array}$ & $\begin{array}{c}\text { Endoscopic sinus } \\
\text { surgery }\end{array}$ & Otolaryngology & Yes & - & U.S.A. & 2018 \\
\hline 2 & $\begin{array}{l}\text { Construction and Validation of a } \\
\text { Low-Cost Laparoscopic } \\
\text { Simulator for Surgical Education } \\
{[14]}\end{array}$ & Laparoscopy & $\begin{array}{l}\text { General } \\
\text { Surgery }\end{array}$ & Yes & $\$ 309$ & U.S.A. & 2013 \\
\hline 3 & $\begin{array}{l}\text { A Low-Cost Platform for } \\
\text { Laparoscopic Simulation } \\
\text { Training [15] }\end{array}$ & Laparoscopy & $\begin{array}{l}\text { Obstetrics and } \\
\text { Gynecology }\end{array}$ & Yes & - & U.S.A. & 2020 \\
\hline 4 & $\begin{array}{l}\text { Face, Content, and Construct } \\
\text { Validity of a Low-Cost Sinus } \\
\text { Surgery Task Trainer [16] }\end{array}$ & $\begin{array}{l}\text { Endoscopic sinus } \\
\text { surgery }\end{array}$ & Otolaryngology & Yes & - & U.S.A. & 2011 \\
\hline 5 & $\begin{array}{l}\text { Teaching and assessing } \\
\text { endoscopic sinus surgery skills } \\
\text { on a validated low-cost task } \\
\text { trainer [17] }\end{array}$ & $\begin{array}{l}\text { Endoscopic Sinus } \\
\text { Surgery }\end{array}$ & Otolaryngology & Yes & - & U.S.A. & 2013 \\
\hline 6 & $\begin{array}{l}\text { Development of a Novel Task } \\
\text { Trainer for Second Trimester } \\
\text { Ultrasound-guided Uterine } \\
\text { Evacuation [18] }\end{array}$ & Uterine Evacuation & $\begin{array}{l}\text { Obstetrics and } \\
\text { Gynecology }\end{array}$ & Yes & - & U.S.A. & 2015 \\
\hline
\end{tabular}




\begin{tabular}{|c|c|c|c|c|c|c|c|}
\hline 7 & $\begin{array}{l}\text { A Simple Cost-Effective Design } \\
\text { for Construction of a } \\
\text { Laparoscopic Trainer [19] }\end{array}$ & Laparoscopy & $\begin{array}{l}\text { General } \\
\text { Surgery }\end{array}$ & No & $\$ 275$ & U.S.A. & 2005 \\
\hline 8 & $\begin{array}{l}\text { An Easily Assembled, Low-Cost } \\
\text { Model for Lateral Canthotomy } \\
\text { Education [20] }\end{array}$ & Lateral canthotomy & $\begin{array}{l}\text { Emergency } \\
\text { Medicine }\end{array}$ & Yes & - & U.S.A. & 2021 \\
\hline 9 & $\begin{array}{l}\text { A Novel Low-Cost Sinus } \\
\text { Surgery Task Trainer [21] }\end{array}$ & Sinus surgery & Otolaryngology & Yes & $>\$ 5$ & U.S.A. & 2011 \\
\hline 10 & $\begin{array}{l}\text { A model for training and } \\
\text { evaluation of myringotomy and } \\
\text { tube placement skills [22] }\end{array}$ & $\begin{array}{l}\text { Myringotomy and } \\
\text { Tube Insertion }\end{array}$ & Otolaryngology & Yes & - & U.S.A. & 2011 \\
\hline 11 & $\begin{array}{l}\text { Five Really Easy Steps to Build } \\
\text { a Homemade Low-Cost } \\
\text { Simulator [23] }\end{array}$ & $\begin{array}{l}\text { Endoscopic } \\
\text { Surgery }\end{array}$ & $\begin{array}{l}\text { General } \\
\text { Surgery }\end{array}$ & Yes & $\begin{array}{l}€ 33.67 \\
\sim \$ 39.43\end{array}$ & Portugal & 2012 \\
\hline 12 & $\begin{array}{l}\text { Use of 3-Dimensional Printing to } \\
\text { Create Patient-Specific Thoracic } \\
\text { Spine Models as Task Trainers } \\
{[24]}\end{array}$ & Thoracic Epidural & Anesthesiology & Yes & - & U.S.A. & 2017 \\
\hline 13 & $\begin{array}{l}\text { Novel Low-Cost, Low-Fidelity } \\
\text { Hemorrhoidectomy Task } \\
\text { Trainers [25] }\end{array}$ & Hemorrhoidectomy & $\begin{array}{l}\text { General } \\
\text { Surgery }\end{array}$ & Yes & - & U.S.A. & 2020 \\
\hline 14 & $\begin{array}{l}\text { Development and evaluation of a } \\
\text { low-cost part-task trainer for } \\
\text { laparoscopic repair of inguinal } \\
\text { hernia in boys and the } \\
\text { acquisition of basic laparoscopy } \\
\text { skills [26] }\end{array}$ & Laparoscopy & $\begin{array}{l}\text { General } \\
\text { Surgery }\end{array}$ & Yes & - & France & 2020 \\
\hline 15 & $\begin{array}{l}\text { Development and Validation of a } \\
\text { Modular Endoscopic Ear } \\
\text { Surgery Skills Trainer [27] }\end{array}$ & $\begin{array}{c}\text { Endoscopic Ear } \\
\text { Surgery }\end{array}$ & Otolaryngology & Yes & $\$ 15$ & U.S.A. & 2017 \\
\hline
\end{tabular}




\begin{tabular}{|c|c|c|c|c|c|c|c|}
\hline 16 & $\begin{array}{l}\text { A Simple, Low-Cost Platform } \\
\text { for Basic Laparoscopic Skills } \\
\text { Training [28] }\end{array}$ & Laparoscopy & $\begin{array}{l}\text { General } \\
\text { Surgery }\end{array}$ & Yes & - & $\begin{array}{l}\text { Palestine/ } \\
\text { Israel }\end{array}$ & 2008 \\
\hline 17 & $\begin{array}{l}\text { Construct Validity, Assessment } \\
\text { of the Learning Curve, and } \\
\text { Experience of Using a Low-Cost } \\
\text { Arthroscopic Surgical Simulator } \\
\text { [29] }\end{array}$ & Arthroscopy & $\begin{array}{l}\text { Orthopedic } \\
\text { Surgery }\end{array}$ & Yes & _ & $\begin{array}{l}\text { United } \\
\text { Kingdom }\end{array}$ & 2017 \\
\hline 18 & $\begin{array}{l}\text { Fabrication and validation of a } \\
\text { low-cost, medium-fidelity } \\
\text { silicone injection molded } \\
\text { endoscopic sinus surgery } \\
\text { simulation model [30] }\end{array}$ & $\begin{array}{c}\text { Endoscopic sinus } \\
\text { surgery }\end{array}$ & Otolaryngology & Yes & - & U.S.A. & 2016 \\
\hline 19 & $\begin{array}{l}\text { Development and Assessment of } \\
\text { a Low-Cost 3D-printed Airway } \\
\text { Model for Bronchoscopy } \\
\text { Simulation Training [31] }\end{array}$ & Bronchoscopy & Pulmonology & Yes & $\begin{array}{c}\text { AUD } \$ 40 \\
\text { USD } \\
\$ 29.02\end{array}$ & Australia & 2016 \\
\hline 20 & $\begin{array}{l}\text { Every Surgical Resident Should } \\
\text { Know How to Perform a } \\
\text { Cricothyrotomy: An Inexpensive } \\
\text { Cricothyrotomy Task Trainer for } \\
\text { Teaching and Assessing Surgical } \\
\text { Trainees [32] }\end{array}$ & Cricothyrotomy & $\begin{array}{l}\text { Emergency } \\
\text { Medicine }\end{array}$ & Yes & - & U.S.A. & 2015 \\
\hline 21 & $\begin{array}{l}\text { A Low-Cost, Reusable, Ballistic } \\
\text { Gelatin Ultrasound Phantom for } \\
\text { Simulation of Glenohumeral } \\
\text { Intraarticular Injections [33] }\end{array}$ & $\begin{array}{l}\text { Glenohumeral joint } \\
\text { injection }\end{array}$ & $\begin{array}{l}\text { Emergency } \\
\text { Medicine }\end{array}$ & Yes & $\$ 85$ & U.S.A. & 2017 \\
\hline 22 & $\begin{array}{l}\text { Evaluation of skills acquisition } \\
\text { using a new low-cost tool for } \\
\text { CPR self-training [34] }\end{array}$ & $\begin{array}{l}\text { Cardiopulmonary } \\
\text { Resuscitation }\end{array}$ & $\begin{array}{l}\text { Emergency } \\
\text { Medicine }\end{array}$ & Yes & $\begin{array}{l}€ 150 \\
\text { Approx. } \\
\$ 175.67\end{array}$ & Portugal & 2018 \\
\hline 23 & $\begin{array}{l}\text { Construction of an Affordable } \\
\text { Lumbar Neuraxial Block Model } \\
\text { Using 3D Printed Materials [35] }\end{array}$ & $\begin{array}{c}\text { Lumbar Neuraxial } \\
\text { Block }\end{array}$ & Anesthesiology & No & $>\$ 400$ & U.S.A. & 2019 \\
\hline 24 & $\begin{array}{l}\text { Implementation of Low-Cost } \\
\text { Obstetric Hemorrhage } \\
\text { Simulation Training Models for } \\
\text { Resident Education [36] }\end{array}$ & $\begin{array}{c}\text { Obstetric } \\
\text { Hemorrhage }\end{array}$ & $\begin{array}{l}\text { Obstetrics and } \\
\text { Gynecology }\end{array}$ & Yes & $\sim \$ 300$ & U.S.A. & 2019 \\
\hline
\end{tabular}




\begin{tabular}{|c|c|c|c|c|c|c|c|}
\hline 25 & $\begin{array}{l}\text { Introducing 3D printed models } \\
\text { of the upper urinary tract for } \\
\text { high-fidelity simulation of } \\
\text { retrograde intrarenal surgery [37] }\end{array}$ & $\begin{array}{c}\text { Retrograde } \\
\text { intrarenal surgery }\end{array}$ & Urology & No & $\begin{array}{c}\quad € 200-400 \\
\sim \text { USD 234-468 }\end{array}$ & Italy & 2021 \\
\hline 26 & $\begin{array}{l}\text { A Low-Cost Priapism } \\
\text { Detumescence Simulator for } \\
\text { Emergency Medicine Residents } \\
{[38]}\end{array}$ & $\begin{array}{l}\text { Ischemic } \\
\text { Priapism }\end{array}$ & $\begin{array}{l}\text { Emergency } \\
\text { Medicine }\end{array}$ & Yes & $\sim 25$ & U.S.A. & 2021 \\
\hline 27 & $\begin{array}{l}\text { Assessment of a mitral valve } \\
\text { replacement skills trainer: A } \\
\text { simplified, low-cost approach } \\
\text { [39] }\end{array}$ & $\begin{array}{l}\text { Mitral Valve } \\
\text { Replacement }\end{array}$ & Cardiology & Yes & $\sim \$ 40$ & U.S.A. & 2013 \\
\hline 28 & $\begin{array}{l}\text { A Cervical Cerclage Task } \\
\text { Trainer for Maternal-Fetal } \\
\text { Medicine Fellows and } \\
\text { Obstetrics/Gynecology Residents } \\
\text { [40] }\end{array}$ & $\begin{array}{l}\text { Cervical } \\
\text { Cerclage }\end{array}$ & $\begin{array}{l}\text { Obstetrics and } \\
\text { Gynecology }\end{array}$ & Yes & $\sim \$ 100$ & U.S.A. & 2012 \\
\hline 29 & $\begin{array}{l}\text { Teaching Vaginal Hysterectomy } \\
\text { via Simulation: Creation } \\
\text { and Validation of the Objective } \\
\text { Skills Assessment Tool for } \\
\text { Simulated Vaginal Hysterectomy } \\
\text { on a Task Trainer and } \\
\text { Performance Among Different } \\
\text { Levels of Trainees [41] }\end{array}$ & $\begin{array}{c}\text { Vaginal } \\
\text { Hysterectomy }\end{array}$ & Gynecology & Yes & - & U.S.A. & 2019 \\
\hline 30 & $\begin{array}{l}\text { Bringing the Skills Laboratory } \\
\text { Home: An Affordable Webcam- } \\
\text { Based Personal Trainer for } \\
\text { Developing Laparoscopic Skills } \\
\text { [42] }\end{array}$ & Laparoscopy & $\begin{array}{l}\text { General } \\
\text { Surgery }\end{array}$ & Yes & - & U.S.A. & 2011 \\
\hline 31 & $\begin{array}{l}\text { Improving Clinical Proficiency } \\
\text { Using a 3-Dimensionally Printed } \\
\text { and Patient-Specific Thoracic } \\
\text { Spine Model as a Haptic Task } \\
\text { Trainer [43] }\end{array}$ & $\begin{array}{l}\text { Thoracic epidural } \\
\text { analgesia }\end{array}$ & Anesthesiology & Yes & - & U.S.A. & 2018 \\
\hline 32 & $\begin{array}{l}\text { Pilot Testing of a Novel } \\
\text { Surgical Simulator for } \\
\text { Endoscopic Zenker's } \\
\text { Diverticulotomy }\end{array}$ & $\begin{array}{c}\text { Endoscopic } \\
\text { Zenker's } \\
\text { diverticulectomy }\end{array}$ & Otolaryngology & Yes & $\$ 2-\$ 20 * 2$ & U.S.A. & 2016 \\
\hline 33 & $\begin{array}{l}\text { A Low-Cost Insertion Trainer } \\
\text { for Resuscitative Endovascular } \\
\text { Balloon Occlusion of the Aorta } \\
\text { (REBOA) [44] }\end{array}$ & REBOA & $\begin{array}{l}\text { Emergency } \\
\text { Medicine }\end{array}$ & Yes & - & U.S.A. & 2020 \\
\hline
\end{tabular}




\begin{tabular}{|c|c|c|c|c|c|c|c|}
\hline 34 & $\begin{array}{l}\text { Development of a Cost-Effective } \\
\text { Pediatric Intubation Task Trainer } \\
\text { for Rural Medical Education } \\
\text { [45] }\end{array}$ & Intubation & Pediatrics & Yes & - & Canada & 2020 \\
\hline 35 & $\begin{array}{l}\text { Gastroschisis Simulation Model: } \\
\text { Pre- surgical Management } \\
\text { Technical Report [46] }\end{array}$ & $\begin{array}{l}\text { Pre-Surgical } \\
\text { Management }\end{array}$ & Pediatrics & No & $\sim \$ 21.75^{* 2}$ & U.S.A. & 2017 \\
\hline 36 & $\begin{array}{l}\text { Making the Cut: Implementing a } \\
\text { Low Cost, Low Fidelity } \\
\text { Simulation Model for Teaching } \\
\text { Emergency Thoracotomy } \\
\text { Procedure [47] }\end{array}$ & Thoracotomy & $\begin{array}{l}\text { Emergency } \\
\text { Medicine }\end{array}$ & Yes & - & U.S.A. & 2020 \\
\hline 37 & $\begin{array}{l}\text { In-utero stenting: development } \\
\text { of a low-cost high-fidelity task } \\
\text { trainer [48] }\end{array}$ & Stent placement & $\begin{array}{l}\text { Obstetrics and } \\
\text { Gynecology }\end{array}$ & No & $\sim \$ 60$ & U.S.A. & 2009 \\
\hline 38 & $\begin{array}{l}\text { Development of a Novel } \\
\text { Ultrasound-guided Peritonsillar } \\
\text { Abscess Model for Simulation } \\
\text { Training [49] }\end{array}$ & $\begin{array}{l}\text { Drainage of } \\
\text { peritonsillar } \\
\text { abscess }\end{array}$ & $\begin{array}{l}\text { Emergency } \\
\text { Medicine }\end{array}$ & Yes & $\sim<\$ 110$ & U.S.A. & 2018 \\
\hline 39 & $\begin{array}{l}\text { A novel biosimulation task } \\
\text { trainer for the deliberate practice } \\
\text { of resuscitative } \\
\text { hysterotomy [50] }\end{array}$ & $\begin{array}{l}\text { Resuscitative } \\
\text { hysterectomy }\end{array}$ & $\begin{array}{l}\text { Emergency } \\
\text { Medicine }\end{array}$ & Yes & $\$ 28.25^{* 2}$ & U.S.A. & 2018 \\
\hline
\end{tabular}

*1 All prices are approximate and subject to variation.

*2 Cost not inclusive of pre-existing and available mannikins and 3D printing devices.

The development and cost effectiveness of various low-cost simulators.

After extracting the required data from the above publications, we managed to quantify the distribution of the locations in which the simulators are developed. These numbers were initially represented by continent and were then further delineated by country. 


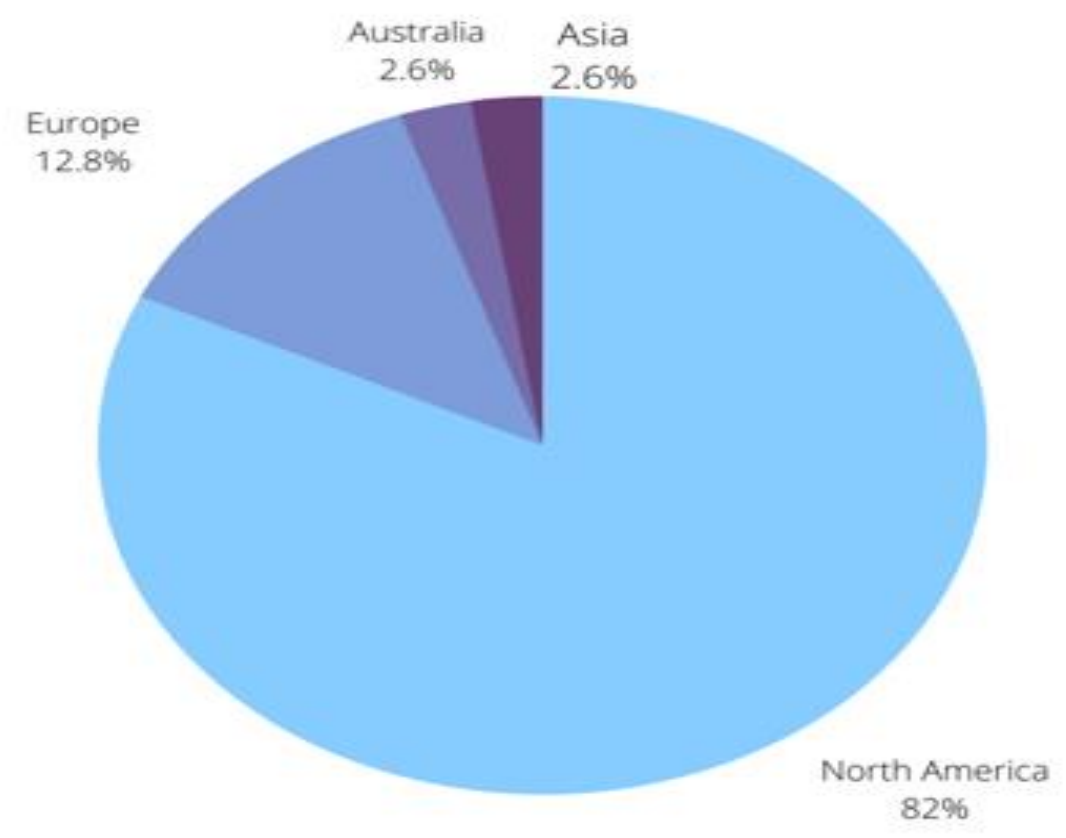

\section{Approximate \% publications per continent}

Figure 5. depicts the distribution of the simulators across different continents

Of the 39 simulators detailed in the above publications, 32, i.e., $82 \%$ were developed in North America, $12.8 \%$ of the models were developed in Europe, 2.6\% were developed in Asia, and an additional $2.6 \%$ of the simulators were developed in Australia. Thus, the information shows that the development of simulators is primarily concentrated in North America, followed by Europe, Asia, and Australia, respectively, as illustrated in figure 5.

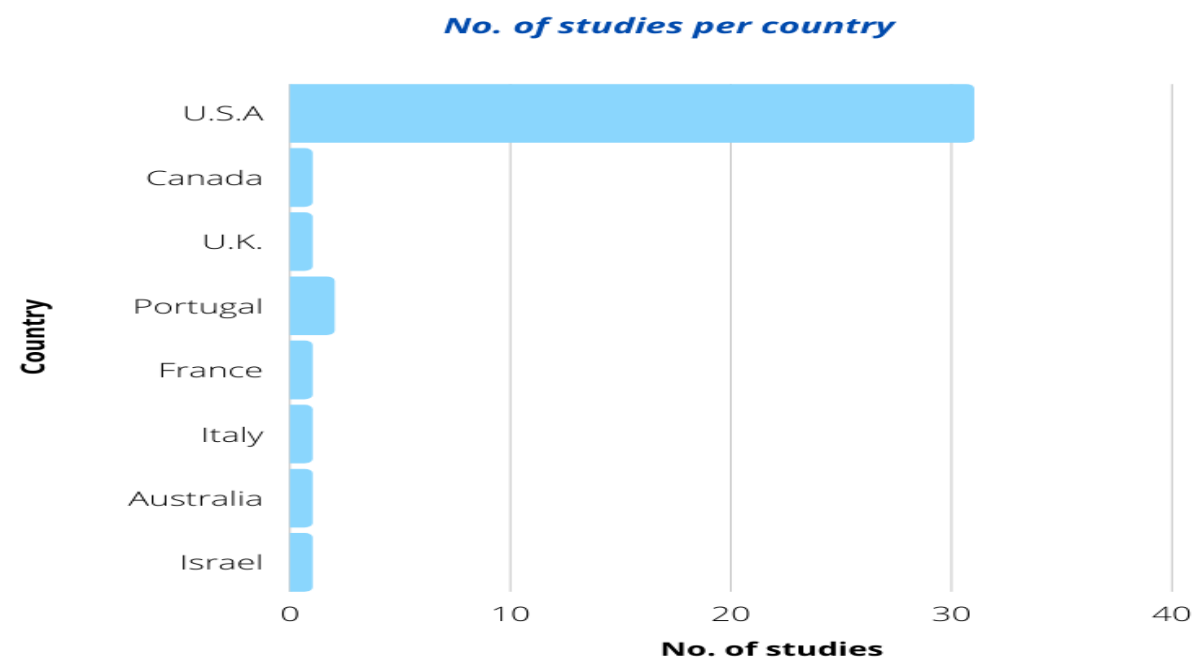

Figure 6 . The distribution of publications across countries. 
The data was then branched out to include the development of simulators by country rather than a continent. The above graph in figure 6 shows that the U.S.A dominates the development of lowcost task trainers in North America with 31 out of 39, i.e., approximately $79.5 \%$ of the developments being made there. This was followed by $5.1 \%$ (i.e., 2 out of 39) of the publications being from Portugal in Europe. The remaining six publications comprised devices developed in Canada, U.K., France, Italy, Australia, and Israel/Palestine (2.6\% each).

\section{No. of task trainers by price range}

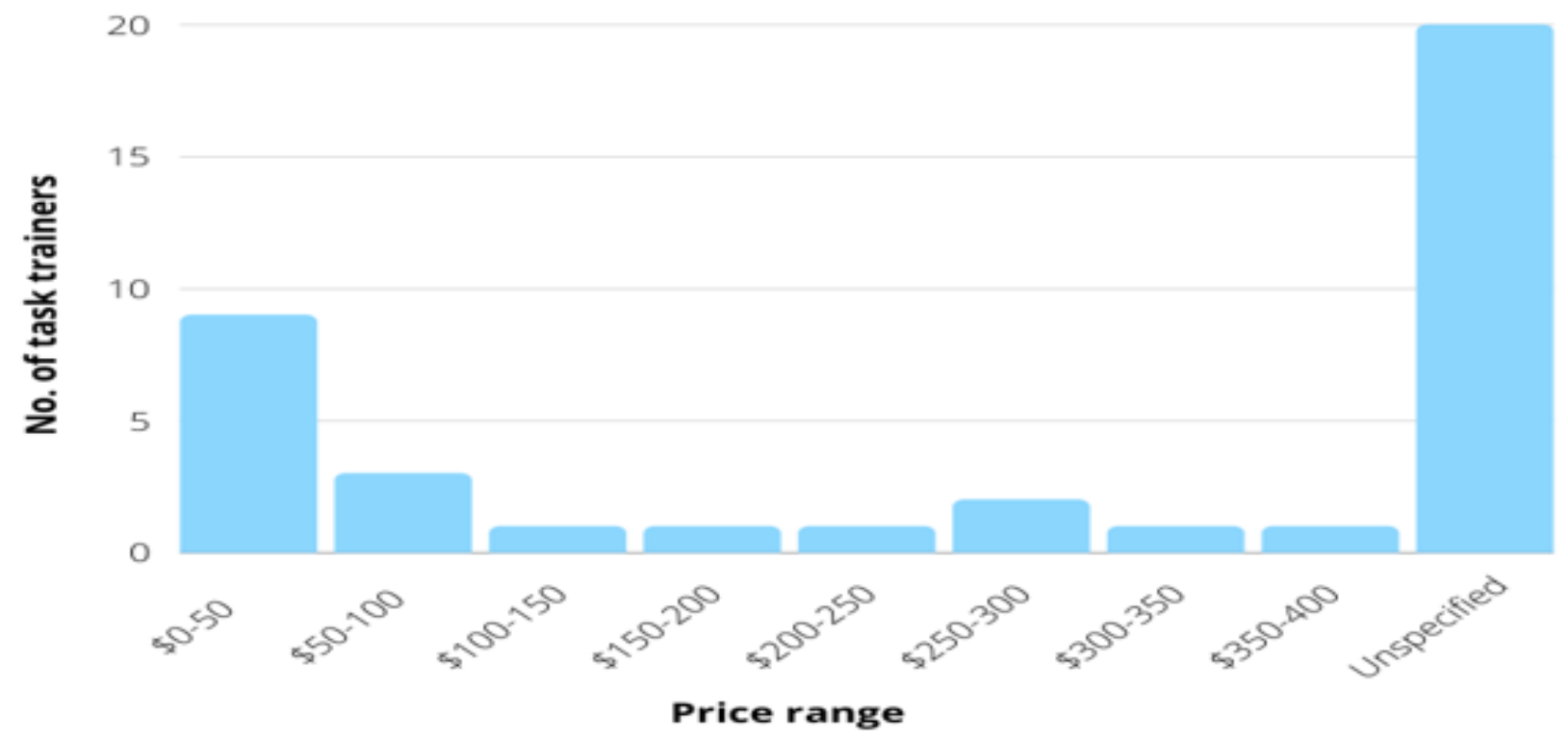

Figure 7. The price ranges of low-cost simulators

In terms of cost and resource expenditure, most publications left cost ranges unspecified while a majority, i.e., 9 of the simulators $(23 \%)$ cost between $0-50$ dollars. The minimum and maximum costs derived from the selected studies were $>5 \$$ and $\sim 400 \$$, respectively. 


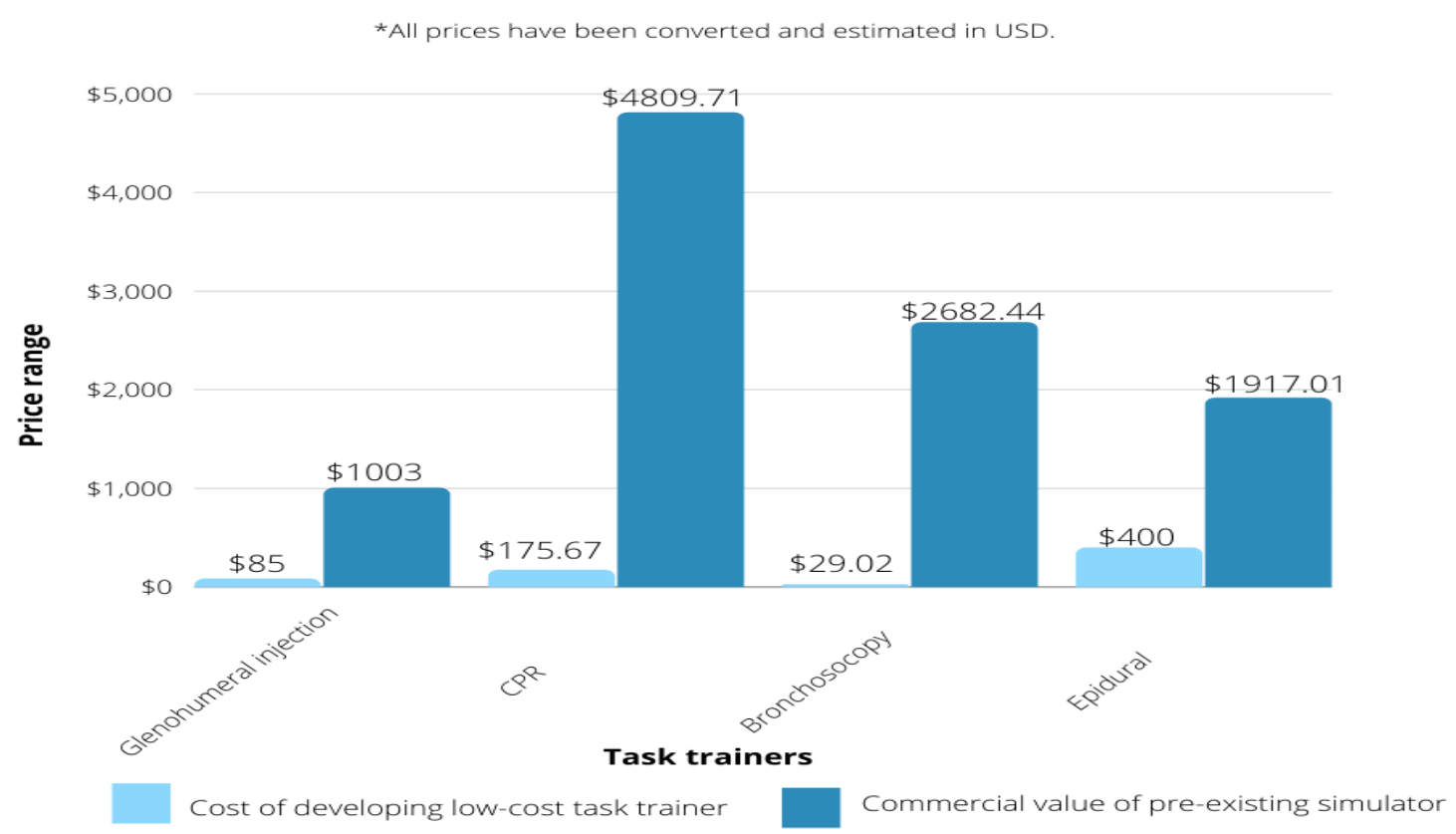

Figure 8. Cost comparison of selected low-cost task trainers and their commercial counterparts

The above graph compares the prices of selected low-cost task trainers from the included articles. It compares them to the prices of commercial simulators produced by prominent medical simulation companies, adapted to have additional functions relevant to the primary procedure at a higher price.

For reference, only four procedures have been contrasted for ease and accuracy of comparability. A low-cost intra-articular joint injection trainer outlined in a study listed above cost approximately $\$ 85$ while its commercial counterpart produced by GT Simulators in the U.S.A. costs $\sim 1003$ [51]. Therefore, the collected data suggest that the commercial device 11.8, i.e., approximately 12 times more than the low-cost trainer.

Furthermore, a low-cost individually developed CPR feedback model detailed in an above study cost about $\$ 175.67$. In comparison, the retail price of a similar program developed by Simulaids costs about $\$ 4809.71$ (i.e., 27 times the price of the low-cost device) [52].

Similarly, bronchoscopy and epidural simulators developed by Simulaids are 92.4 and 4.8 times more costly than their accessible equivalents, respectively [53][54]. 


\section{The procedural skills practiced using low-cost simulators.}

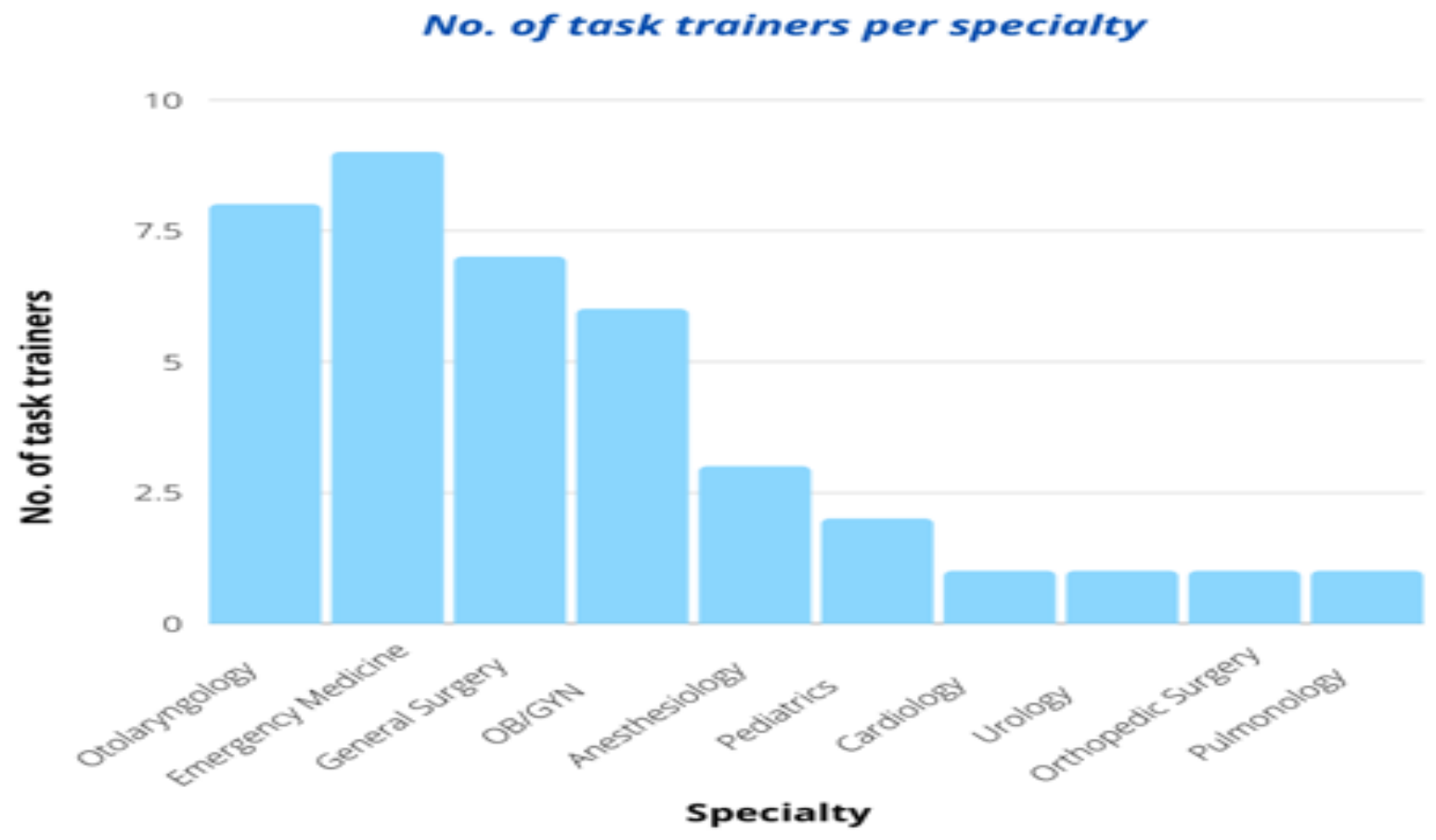

Figure 9. Specialty distribution of low-cost simulators

As presented in figure 9 above, the bulk of the simulators were developed to be used in the field of Emergency Medicine (23\%), followed by Otolaryngology (20.5\%), General Surgery (18\%), OB/GYN (15.4\%), Anesthesiology ( 8\%) and so on.

The simulated procedures carried out were predominantly endoscopic, comprising $33.3 \%$ of the compiled procedures. Procedures involving removal and cutting formed a combined total of $18 \%$ of the simulators $(7.7 \%$ and $10.3 \%$, respectively). Epidural simulators occurred least, at a frequency of $5.1 \%$. Other procedures and practical skills not under these definitions constitute $43.6 \%$ of the 39 studies, as shown in figure 10 below. 


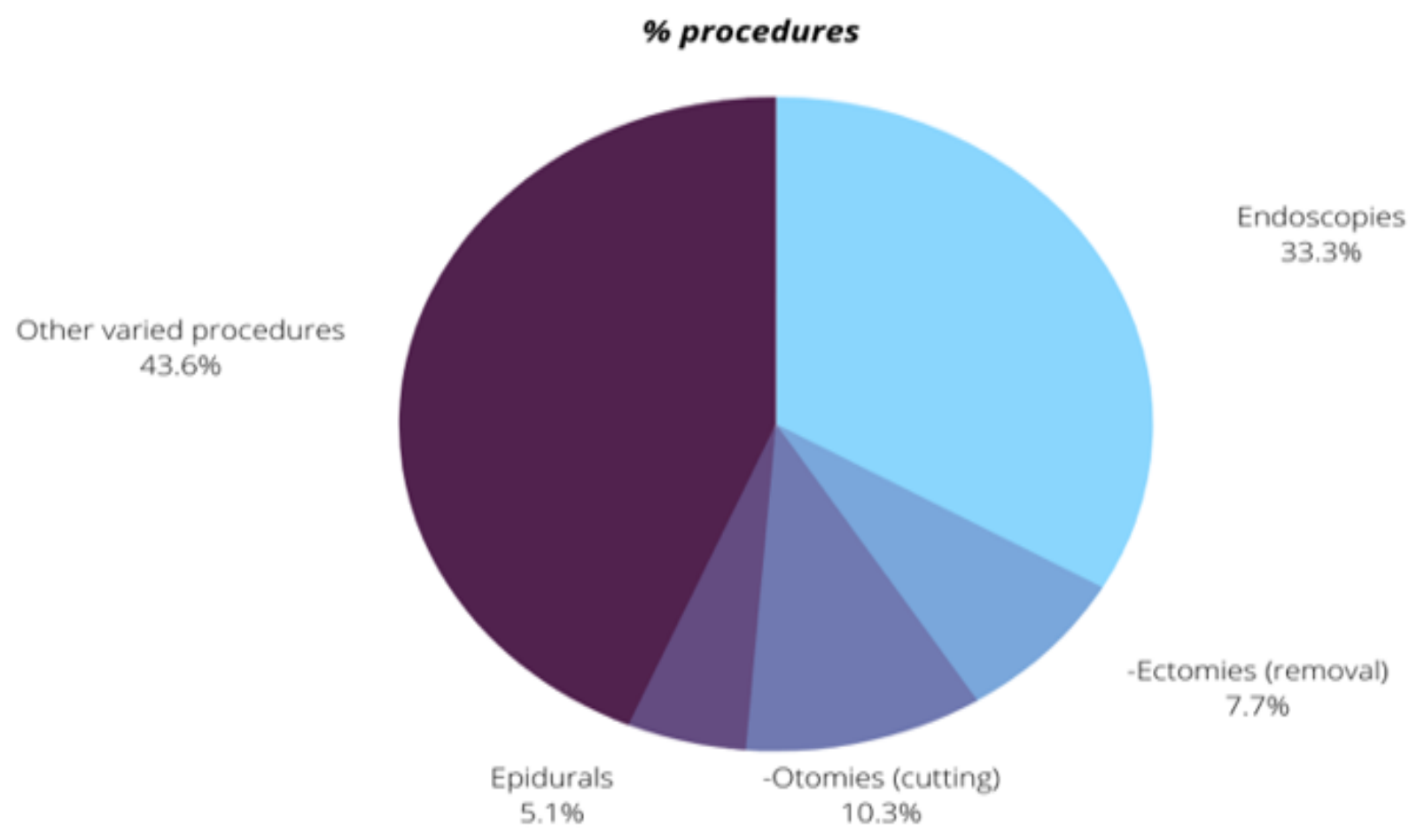

Figure 10. Type of procedures covered by low-cost simulators

\section{Whether the use of low-cost simulators are ubiquitous or localized in LMICs and/or HICs.}

All the simulators have been developed in high-income countries (HICs) from the data given above. While most studies claim to have used accessible materials available in low resource areas, not many publications include a price range that can be used to quantify the value of the simulator and classify it as low-cost. Approximately $80 \%$ of the simulators were developed in the U.S.A, while the remaining $10 \%$ were developed in affluent, high resource countries spread across Asia, Europe, Australia, and North America.

\section{Discussion}

Simulation-based learning has proven itself to be a valuable tool in medical education. In a world where medicine is constantly evolving and adapting itself to complement advancements in healthcare and the need for well-versed healthcare professionals. Considering the increasing demand for medical attention worldwide, simulation-based learning has become a more reasonable teaching methodology than ever before. 
However, the benefits provided by simulators of varying fidelities are often restricted to resource rich, high-income countries, as evidenced by our results. Although efforts have been made to universalize complex simulating devices in low-middle income countries, the results of this review suggest that definitions of low-cost vary following the many privileges available to individuals in high income countries. Different values are assigned to labor, time, assembly, and apparatus. Additionally, given the vast gap between the development of medical systems in HICs and LMICS, the priorities and goals of students and professionals in these places differ in terms of the development of such low-cost models. While studies conducted in HICs focused on debriefing, consultation with standardized patients, diagnosis, skills acquisition, and management, those in LMICs are possibly more likely to give greater importance to the prolonged study of identification and treatment of the condition itself. Students and professionals in LMICs may be more inclined to create and validate more economical models to implement them in medical education as a more permanent alternative. [55]

One would assume that low-cost simulators would have a higher demand in LMICs where they would benefit professionals more. However, our findings show that all the selected task trainers were developed in HICs with an approach based primarily on innovation rather than accessibility. This objective does not align with the aims of the distribution and development of simulated models in LMICs.

Furthermore, our results show that out of the 84 publications, 39 were deemed relevant to the categories "low-cost" and "task trainer". From the selected sample, 20 omitted the costs of their task trainers while the other 19 gave approximate prices. Studies suggest development and application of simulations in medical education may be restricted due to the lack of emphasis on outcome-based economic analysis in this field. Due to the qualitative nature of the data collected from instances in which simulations are employed (i.e., student feedback, outcomes, opinions on feasibility, and versatility) it is harder to quantify and give value to subjective information in a context that is relevant to a cost-benefit (CBA) or cost-effectiveness analysis (CEA). Adding to this conundrum, testimonials from those surveyed may vary and contradict final outcomes; someone who did not believe that simulation added significant value to their medical education may go on to become an excellent physician. In this scenario, the outcome is good but not as a result of what is being assessed. [56] 
Such remediable barriers create a disinclination towards investing in simulation technology and its dissemination in LMICs at reasonable prices.

Considering the lack of distribution of resources required to create an efficient simulation-based learning environment, improvements that can be made in simulation education going ahead may be to inculcate experiential alternatives that comply with the criteria required to provide an essential simulated environment. Kneebone et al. suggest that thinking broadly and focusing on "simulations rather than simulators" may prove to be a more holistic approach. [57] Options that have been explored include global tie ups with established simulation centers [58], using "selective abstraction" in a distributed simulation to include the essential components of a simulation in an economical, remote and functional environment [57] and consolidating two or more simulation modalities to create an affordable and equally realistic hybrid simulation [59].

Some statistics suggest that hospitals in LMICs experienced an estimated $50 \%$ more harmful outcomes than institutions in HICs. [60] Introducing an effective simulation program may help strengthen procedural and communication skills, thereby possibly rectifying and decreasing these numbers.

From the compiled data in figure 9, it can be observed that low-cost task trainers were developed more frequently to practice procedures categorized within Emergency Medicine, followed closely by Otolaryngology. Even so, practicing skills on these trainers refine procedural technique and skills acquisition and enhance theoretical knowledge, communication skills, patient care, and professionalism - skills that are viable in any specialty of medicine.

Moreover, a vast majority of the procedures classified under Emergency Medicine in the publications can branch out into other specialties, including Obstetrics, Gynecology, and Urology. [61]

It is noteworthy that while medical simulations are invaluable additions to the current scheme of medical education, they are still developing and expensive to produce, validate and propagate. However, the benefits provided by such methods have been proven to be an on par augmented correspondent to traditional teaching methods, especially in conjunction with the forenamed alternatives [62]. 


\section{Conclusion}

After a careful review of the accessibility of low-cost simulations as a means of teaching in medical education, we can conclude that more advanced methods of teaching centered around realism are sparse in low-middle income countries and vary in terms of advancement, feasibility, cost effectiveness, and resource availability. Therefore, alternatives and initiatives should be established to propagate a new, more immersive, simulation-centric medical pedagogy of which a relatively large sample can reap benefits. We have set apart parameters by which we can monitor the spread of the technology internationally and determined from our limited findings that simulation is a valuable tool that can significantly benefit multiple facets of the education of tomorrow's physicians.

\section{References}

[1] M. T. Curtis, D. DiazGranados, and M. Feldman, "Judicious use of simulation technology in continuing medical education,” J. Contin. Educ. Health Prof., vol. 32, no. 4, pp. 255260, 2012, doi: 10.1002/chp.21153.

[2] "assessment_and_feedback_for_residents_and_students-1.pdf."

[3] A. Nuzhat, R. O. Salem, M. S. A. Quadri, and N. Al-Hamdan, "Learning style preferences of medical students: a single-institute experience from Saudi Arabia," Int. J. Med. Educ., vol. 2, pp. 70-73, Aug. 2011, doi: 10.5116/ijme.4e36.d31c.

[4] "To-Err-is-Human-1999--report-brief.pdf."

[5] Spaulding Neuromodulation Center, Spaulding Rehabilitation Hospital, Harvard Medical School, F. Jones, C. Passos-Neto, O. Melro Braghiroli, and Medical School of Bahia, Federal University of Bahia, Salvador, Brazil, "Simulation in Medical Education: Brief history and methodology," Princ. Pract. Clin. Res. J., vol. 1, no. 2, pp. 56-63, Sep. 2015, doi: 10.21801/ppcrj.2015.12.8.

[6] R. E. Sedlack, J. C. Kolars, and J. A. Alexander, "Computer simulation training enhances patient comfort during endoscopy," Clin. Gastroenterol. Hepatol., vol. 2, no. 4, pp. 348352, Apr. 2004, doi: 10.1016/S1542-3565(04)00067-9.

[7] K. Kunkler, "The role of medical simulation: an overview," Int. J. Med. Robot., vol. 2, no. 3, pp. 203-210, 2006, doi: 10.1002/rcs.101.

[8] N. J. Maran and R. J. Glavin, "Low- to high-fidelity simulation - a continuum of medical education?: Low- to high-fidelity simulation," Med. Educ., vol. 37, pp. 22-28, Nov. 2003, doi: 10.1046/j.1365-2923.37.s1.9.x.

[9] "Healthcare Simulation Dictionary," p. 52.

[10] G. Norman, K. Dore, and L. Grierson, "The minimal relationship between simulation fidelity and transfer of learning," Med. Educ., vol. 46, no. 7, pp. 636-647, Jul. 2012, doi: 10.1111/j.1365-2923.2012.04243.x.

[11] C. Massoth et al., "High-fidelity is not superior to low-fidelity simulation but leads to overconfidence in medical students," BMC Med. Educ., vol. 19, no. 1, p. 29, Dec. 2019, doi: 10.1186/s12909-019-1464-7. 
[12] O. Turkot et al., "A Review of Anesthesia Simulation in Low-Income Countries," Curr. Anesthesiol. Rep., vol. 9, no. 1, pp. 1-9, Mar. 2019, doi: 10.1007/s40140-019-00305-4.

[13] Y. Yoshiyasu et al., "Construct validity of a low-cost medium-fidelity endoscopic sinus surgery simulation model," The Laryngoscope, vol. 129, no. 7, pp. 1505-1509, Jul. 2019, doi: 10.1002/lary.27748.

[14] J. Wong, G. Bhattacharya, S. J. Vance, P. Bistolarides, and A. M. Merchant, "Construction and validation of a low-cost laparoscopic simulator for surgical education," J. Surg. Educ., vol. 70, no. 4, pp. 443-450, Aug. 2013, doi: 10.1016/j.jsurg.2013.02.004.

[15] A. P. Ulrich, M. Y. Cho, C. Lam, and V. T. Lerner, "A Low-Cost Platform for Laparoscopic Simulation Training,” Obstet. Gynecol., vol. 136, no. 1, pp. 77-82, Jul. 2020, doi: 10.1097/AOG.0000000000003920.

[16] M. K. Steehler, M. J. Pfisterer, H. Na, H. N. Hesham, M. Pehlivanova, and S. Malekzadeh, "Face, content, and construct validity of a low-cost sinus surgery task trainer," Otolaryngol.--Head Neck Surg. Off. J. Am. Acad. Otolaryngol.-Head Neck Surg., vol. 146, no. 3, pp. 504-509, Mar. 2012, doi: 10.1177/0194599811430187.

[17] M. K. Steehler, E. E. Chu, H. Na, M. J. Pfisterer, H. N. Hesham, and S. Malekzadeh, "Teaching and assessing endoscopic sinus surgery skills on a validated low-cost task trainer," The Laryngoscope, vol. 123, no. 4, pp. 841-844, Apr. 2013, doi: 10.1002/lary.23849.

[18] K. M. Shumard, U. N. Akoma, L. M. Street, B. C. Brost, and J. F. Nitsche, "Development of a novel task trainer for second trimester ultrasound-guided uterine evacuation," Simul. Healthc. J. Soc. Simul. Healthc., vol. 10, no. 1, pp. 49-53, Feb. 2015, doi: 10.1097/SIH.0000000000000063.

[19] D. Ricchiuti, D. A. Ralat, M. Evancho-Chapman, H. Wyneski, J. Cerone, and J. D. Wegryn, "A simple cost-effective design for construction of a laparoscopic trainer," J. Endourol., vol. 19, no. 8, pp. 1000-1002; discussion 1002-1005, Oct. 2005, doi: 10.1089/end.2005.19.1000.

[20] M. Mendes, J. A. Buchanan, M. Sande, and M. E. Moreira, "An Easily Assembled, LowCost Model for Lateral Canthotomy Education," J. Emerg. Med., vol. 60, no. 6, pp. 777780, Jun. 2021, doi: 10.1016/j.jemermed.2021.01.003.

[21] S. Malekzadeh, M. J. Pfisterer, B. Wilson, H. Na, and M. K. Steehler, "A novel low-cost sinus surgery task trainer," Otolaryngol.--Head Neck Surg. Off. J. Am. Acad. Otolaryngol.Head Neck Surg., vol. 145, no. 4, pp. 530-533, Oct. 2011, doi: $10.1177 / 0194599811413373$.

[22] S. Malekzadeh, G. Hanna, B. Wilson, M. Pehlivanova, and G. Milmoe, "A model for training and evaluation of myringotomy and tube placement skills," The Laryngoscope, vol. 121, no. 7, pp. 1410-1415, Jul. 2011, doi: 10.1002/lary.21801.

[23] J. Moreira-Pinto, J. G. Silva, J. L. Ribeiro de Castro, and J. Correia-Pinto, "Five Really Easy Steps to Build a Homemade Low-Cost Simulator," Surg. Innov., vol. 20, no. 1, pp. 95-99, Feb. 2013, doi: 10.1177/1553350612440508.

[24] J. Jeganathan et al., "Use of 3-Dimensional Printing to Create Patient-Specific Thoracic Spine Models as Task Trainers," Reg. Anesth. Pain Med., vol. 42, no. 4, pp. 469-474, Aug. 2017, doi: 10.1097/AAP.0000000000000580.

[25] A. D. Geary, L. I. M. Pernar, and J. F. Hall, "Novel Low-Cost, Low-Fidelity Hemorrhoidectomy Task Trainers," J. Surg. Educ., vol. 77, no. 5, pp. 1285-1288, Oct. 2020, doi: 10.1016/j.jsurg.2020.03.003. 
[26] H. Duboureau, M. Renaud-Petel, C. Klein, and E. Haraux, "Development and evaluation of a low-cost part-task trainer for laparoscopic repair of inguinal hernia in boys and the acquisition of basic laparoscopy skills," J. Pediatr. Surg., vol. 56, no. 4, pp. 674-677, Apr. 2021, doi: 10.1016/j.jpedsurg.2020.05.044.

[27] M. M. Dedmon et al., "Development and Validation of a Modular Endoscopic Ear Surgery Skills Trainer," Otol. Neurotol. Off. Publ. Am. Otol. Soc. Am. Neurotol. Soc. Eur. Acad. Otol. Neurotol., vol. 38, no. 8, pp. 1193-1197, Sep. 2017, doi: 10.1097/MAO.0000000000001485.

[28] A. B. Dayan, A. Ziv, H. Berkenstadt, and Y. Munz, "A simple, low-cost platform for basic laparoscopic skills training," Surg. Innov., vol. 15, no. 2, pp. 136-142, Jun. 2008, doi: $10.1177 / 1553350608318142$.

[29] H. B. Colaco, K. Hughes, E. Pearse, M. Arnander, and D. Tennent, "Construct Validity, Assessment of the Learning Curve, and Experience of Using a Low-Cost Arthroscopic Surgical Simulator," J. Surg. Educ., vol. 74, no. 1, pp. 47-54, Feb. 2017, doi: 10.1016/j.jsurg.2016.07.006.

[30] D. R. Chang et al., "Fabrication and validation of a low-cost, medium-fidelity silicone injection molded endoscopic sinus surgery simulation model," The Laryngoscope, vol. 127, no. 4, pp. 781-786, Apr. 2017, doi: 10.1002/lary.26370.

[31] T. Byrne, S. A. Yong, and D. P. Steinfort, "Development and Assessment of a Low-Cost 3D-printed Airway Model for Bronchoscopy Simulation Training," J. Bronchol. Interv. Pulmonol., vol. 23, no. 3, pp. 251-254, Jul. 2016, doi: 10.1097/LBR.0000000000000257.

[32] J. M. Aho et al., "Every surgical resident should know how to perform a cricothyrotomy: an inexpensive cricothyrotomy task trainer for teaching and assessing surgical trainees," $J$. Surg. Educ., vol. 72, no. 4, pp. 658-661, Aug. 2015, doi: 10.1016/j.jsurg.2014.12.012.

[33] A. Shah, "A Low-Cost, Reusable, Ballistic Gelatin Ultrasound Phantom for Simulation of Glenohumeral Intraarticular Injections," AEM Educ. Train., vol. 2, no. 2, pp. 169-173, Apr. 2018, doi: 10.1002/aet2.10081.

[34] C. Sá-Couto, A. M. Ferreira, D. Almeida, A. Nicolau, and P. Vieira-Marques, "Evaluation of skills acquisition using a new low-cost tool for CPR self-training," Porto Biomed. J., vol. 3, no. 1, p. e8, Aug. 2018, doi: 10.1016/j.pbj.0000000000000008.

[35] K. T. Riutort, W. Clifton, A. Damon, C. Dove, and S. R. Clendenen, "Construction of an Affordable Lumbar Neuraxial Block Model Using 3D Printed Materials," Cureus, vol. 11, no. 10, p. e6033, Oct. 2019, doi: 10.7759/cureus.6033.

[36] A. M. Ramseyer and M. A. Lutgendorf, "Implementation of Low-Cost Obstetric Hemorrhage Simulation Training Models for Resident Education," Mil. Med., vol. 184, no. 11-12, pp. e637-e641, Dec. 2019, doi: 10.1093/milmed/usz098.

[37] L. Orecchia et al., "Introducing 3D printed models of the upper urinary tract for highfidelity simulation of retrograde intrarenal surgery," $3 D$ Print. Med., vol. 7, no. 1, p. 15, Jun. 2021, doi: 10.1186/s41205-021-00105-9.

[38] Z. Hampton, N. Meier, and J. Casey, "A Low-Cost Priapism Detumescence Simulator for Emergency Medicine Residents," Cureus, vol. 13, no. 6, p. e15782, Jun. 2021, doi: 10.7759/cureus. 15782 .

[39] D. G. Greenhouse et al., "Assessment of a mitral valve replacement skills trainer: A simplified, low-cost approach," J. Thorac. Cardiovasc. Surg., vol. 145, no. 1, pp. 54-59.e1, Jan. 2013, doi: 10.1016/j.jtcvs.2012.09.074. 
[40] J. F. Nitsche and B. C. Brost, "A Cervical Cerclage Task Trainer for Maternal-Fetal Medicine Fellows and Obstetrics/Gynecology Residents," Simul. Healthc. J. Soc. Simul. Healthc., vol. 7, no. 5, pp. 321-325, Oct. 2012, doi: 10.1097/SIH.0b013e318259d1a7.

[41] D. R. Malacarne, C. M. Escobar, C. J. Lam, K. L. Ferrante, D. Szyld, and V. T. Lerner, "Teaching Vaginal Hysterectomy via Simulation: Creation and Validation of the Objective Skills Assessment Tool for Simulated Vaginal Hysterectomy on a Task Trainer and Performance Among Different Levels of Trainees," Female Pelvic Med. Reconstr. Surg., vol. 25, no. 4, pp. 298-304, Aug. 2019, doi: 10.1097/SPV.0000000000000558.

[42] S. A. Kobayashi et al., "Bringing the skills laboratory home: an affordable webcam-based personal trainer for developing laparoscopic skills," J. Surg. Educ., vol. 68, no. 2, pp. 105109, Apr. 2011, doi: 10.1016/j.jsurg.2010.09.014.

[43] J. Bortman et al., "Improving Clinical Proficiency Using a 3-Dimensionally Printed and Patient-Specific Thoracic Spine Model as a Haptic Task Trainer," Reg. Anesth. Pain Med., vol. 43, no. 8, pp. 819-824, Nov. 2018, doi: 10.1097/AAP.0000000000000821.

[44] R. Walsh, C. Lei, K. H. Palm, R. J. Van Nostrand, and Z. Sletten, "A Low-Cost Insertion Trainer for Resuscitative Endovascular Balloon Occlusion of the Aorta (REBOA)," Cureus, vol. 12, no. 8, p. e9729, Aug. 2020, doi: 10.7759/cureus.9729.

[45] S. Tanya and A. Dubrowski, "Development of a Cost-Effective Pediatric Intubation Task Trainer for Rural Medical Education," Cureus, Jan. 2020, doi: 10.7759/cureus.6604.

[46] O. Rosen and R. M. Angert, "Gastroschisis Simulation Model: Pre-surgical Management Technical Report," Cureus, vol. 9, no. 3, p. e1109, Mar. 2017, doi: 10.7759/cureus.1109.

[47] A. O’Connell, X. C. Zhang, M. Crossman, S. Misuro, and M. Stobart-Gallagher, "Making the Cut: Implementing a Low Cost, Low Fidelity Simulation Model for Teaching Emergency Thoracotomy Procedure," Cureus, vol. 12, no. 5, p. e8088, May 2020, doi: 10.7759/cureus.8088.

[48] J. F. Nitsche et al., "In-utero stenting: development of a low-cost high-fidelity task trainer," Ultrasound Obstet. Gynecol. Off. J. Int. Soc. Ultrasound Obstet. Gynecol., vol. 34, no. 6, pp. 720-723, Dec. 2009, doi: 10.1002/uog.7311.

[49] V. Ng, J. Plitt, and D. Biffar, "Development of a Novel Ultrasound-guided Peritonsillar Abscess Model for Simulation Training," West. J. Emerg. Med., vol. 19, no. 1, pp. 172176, Jan. 2018, doi: 10.5811/westjem.2017.11.36427.

[50] L. Lau, D. Papanagnou, E. Smith, C. Waters, E. Teixeira, and X. C. Zhang, "A novel biosimulation task trainer for the deliberate practice of resuscitative hysterotomy," $A d v$. Simul. Lond. Engl., vol. 3, p. 19, 2018, doi: 10.1186/s41077-018-0078-1.

[51] "Shoulder Injection Model - GTSimulators.com." https://www.gtsimulators.com/collections/joint-injection-trainers/products/shoulderinjection-model-sb15091 (accessed Aug. 24, 2021).

[52] "Heartisense ${ }^{\circledR}$ CPR Feedback Premium Kit - 6 Pack," Simulaids. https://simulaids.co.uk/product/heartisense-cpr-feedback-premium-kit-6-pack/ (accessed Aug. 24, 2021).

[53] "TruCorp AirSim Child Combo Bronchi X Airway Management Trainer," Simulaids. https://simulaids.co.uk/product/trucorp-airsim-child-combo-bronchi-X-airway-managementtrainer/ (accessed Aug. 24, 2021).

[54] "Spinal Injection Simulator," Simulaids. https://simulaids.co.uk/product/spinal-injectionsimulator/ (accessed Aug. 24, 2021). 
[55] L. Puri et al., "Enhancing quality of medical care in low income and middle income countries through simulation-based initiatives: recommendations of the Simnovate Global Health Domain Group," BMJ Simul. Technol. Enhanc. Learn., vol. 3, no. Suppl 1, pp. S15S22, Mar. 2017, doi: 10.1136/bmjstel-2016-000180.

[56] S. Maloney and T. Haines, "Issues of cost-benefit and cost-effectiveness for simulation in health professions education," Adv. Simul., vol. 1, no. 1, p. 13, Jan. 2016, doi: 10.1186/s41077-016-0020-3.

[57] R. Kneebone et al., "Distributed simulation - Accessible immersive training," Med. Teach., vol. 32, no. 1, pp. 65-70, Jan. 2010, doi: 10.3109/01421590903419749.

[58] K. Snowden et al., "Spearheading Simulation in a Middle-Income Country: An International Collaboration," Clin. Simul. Nurs., vol. 50, pp. 74-78, Jan. 2021, doi: 10.1016/j.ecns.2020.06.007.

[59] W. J. Brown and R. A. W. Tortorella, "Hybrid medical simulation - a systematic literature review," Smart Learn. Environ., vol. 7, no. 1, p. 16, Dec. 2020, doi: 10.1186/s40561-02000127-6.

[60] A. K. Jha, I. Larizgoitia, C. Audera-Lopez, N. Prasopa-Plaizier, H. Waters, and D. W. Bates, "The global burden of unsafe medical care: analytic modelling of observational studies," BMJ Qual. Saf., vol. 22, no. 10, pp. 809-815, Oct. 2013, doi: 10.1136/bmjqs2012-001748.

[61] R. P. Ten Eyck, "Simulation in emergency medicine training," Pediatr. Emerg. Care, vol. 27, no. 4, pp. 333-341; quiz 342-344, Apr. 2011, doi: 10.1097/PEC.0b013e3182131fe0.

[62] "Simulation-Based Learning: No Longer a Novelty in Undergraduate Education." https://ojin.nursingworld.org/MainMenuCategories/ANAMarketplace/ANAPeriodicals/OJI N/TableofContents/Vol-23-2018/No2-May-2018/Articles-Previous-Topics/SimulationBased-Learning-Undergraduate-Education.html (accessed Aug. 26, 2021). 